\title{
“O Amor Que Temos É Terrível”: Os Contatos Entre As Realezas Grega E Cuxita Manifestos Na União De Perseu E Andrômeda
}

\author{
Marina Pereira Outeiro ${ }^{1}$
}

RESUMO

Discorremos acerca dos contatos estabelecidos entre as realezas grega e cuxita -, a partir do mito de Perseu e Andrômeda - retomado na Atenas Clássica, por Eurípides e Sófocles, em suas versões de Andrômeda, e pelos ceramistas que representaram o encontro entre o herói grego e a princesa cuxita. Privilegiamos os aportes teóricos do Gênero e da Arqueologia de Gênero para analisar os papéis atribuídos às mulheres em ambas as sociedades. Para o exame da documentação, textual e imagética, favorecemos o uso da Semiótica e Análise do Conteúdo.

Palavras-chave

Grécia; Cuxe; Andrômeda; Perseu

${ }^{1}$ Doutoranda em história (UERJ). E-mail: marina_outeiro@hotmail.com. 


\section{Questões preliminares}

Em um dos artigos da coletânea Mitos, Emblemas, Sinais: morfologia e história (1989), Carlo Ginzburg discorre acerca de como o mito de Perseu e Andrômeda - tal como narrado por Ovídio - foi incluído no imaginário erótico europeu do século XVI, destacando o quadro de Ticiano "Perseu e Andromeda". Ginzburg dedica-se a analisar em que medida existiria uma dependência entre texto e imagem, considerando os meios pelos quais a obra ovidiana foi difundida através de alegorias e vulgarizações ao longo dos séculos. Ticiano não dominava o latim, de sorte que o acesso ao conteúdo do texto mítico deu-se por outros meios, "não de Ovídio, mas a vulgarização de um romance alexandrino. Porém sabemos que Ticiano extraiu de Ovídio a inspiração para a maioria de suas 'poesias' mitológicas" (Ginzburg, 2014, p. 126-27).

Naturalmente, não se encontrava entre os objetivos do historiador escrutinar o mito do herói grego e da princesa cuxita em si, ainda que Ginzburg mencione sumariamente a cronologia medieval que possibilitou os processos de vulgarização do texto ovidiano. Entretanto, o mito de Perseu e Andrômeda resistiu à passagem dos séculos com força suficiente para inspirar artistas e povoar o imaginário erudito e popular europeu dos anos de 1500. Tal fato parece-nos atestar que sua carga de significado pouco esmoreceu desde sua inicial difusão, quando atraiu o interesse de tragediógrafos e ceramistas áticos do século $\mathrm{V}$ a.C., indivíduos esses que representaram o encontro de Perseu e Andrômeda por meio de texto e imagem.

Entendemos que o mito de Perseu e Andrômeda pode ser considerado, enquanto ponto de partida, para o desenvolvimento de um estudo histórico centrado nas relações estabelecidas entre Grécia e Cuxe durante a Antiguidade nomeadamente, no século V a.C., manifesta na aproximação entre as realezas grega e cuxita. De fato, as origens de Perseu eram conhecidas desde o século VIII a.C., sendo mencionadas na poesia de Homero (Il. 14, 319-20), como em: “da Acrisíone Dânae, belos-tornozelos, que gerou Perseu, entre os homens sobranceiro" " Da mesma forma, as façanhas de Perseu foram cantadas por Hesíodo (Teo. p.280-81). O autor registrou a luta do personagem mítico

\footnotetext{
${ }^{2}$ Vecelli, Tiziano. Perseus e Andrômeda. ca 1554-1556. Pintura, óleo sobre tela, $175 \times 189.5 \mathrm{~cm}$. Atualmente integra The Wallace Collection, da coleção de arte de Hertford House, em Londres.

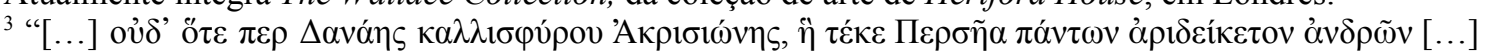
(Il. 14, 319-320)".
} 
contra a górgona Medusa e, conforme escreveu: "lhe decapitou o pescoço, surgiram o grande Aurigládio e o cavalo Pégaso"4.

E, novamente, através do testemunho da poesia homérica, podemos assumir que os gregos tivessem travado contatos com povos africanos que, distinguidos dos egípcios, foram alcunhados de Aithiopees (Aï1o $\left.\pi \tilde{\eta} \varepsilon \zeta^{5}\right)$. Lê-se na Odisseia: “os etíopes, distantes moradores - etíopes, divididos em dois grupos, varões dos extremos: uns, onde Hiperion mergulha, outros onde levanta"6 $(O d$. I, 22-4). Entre os gregos, o termo foi empregado mediante um processo de classificação - orientado por questões referentes à compleição física, localização geográfica e identificação étnica, para designar homens e mulheres de cor de pele escura e negra que ocupavam diversas áreas da África.

Dessa forma, é compreensível que Homero empregasse o termo "etíopes" para denominar os cuxitas, mesmo, que desconhecesse a localização exata de seu território. Tal pressuposto não mitiga o fato de que, como apontou Snowden, "embora os gregos tenham recebido alguns relatos sobre a napatana XXV dinastia etíope, foi sobre os etíopes do segundo período ou período meroítico (542-339/50 a.C.) com os quais os gregos, e depois os romanos, estavam mais familiarizados" (Snowden, 1970, p. 115).

Por sua vez, o mito de Andrômeda adquiriu maior visibilidade, ao ser entrecruzado com as aventuras de Perseu. Filha do rei Cefeu e da rainha Cassiopeia, Andrômeda foi ofertada como sacrifício ao monstro marinho enviado por Posêidon que devastava Méroe. Retornado da caçada à Medusa, Perseu sobrevoou ${ }^{7}$ a cidade e avistou Andrômeda amarrada a um rochedo junto ao mar. Os jovens teriam se apaixonado instantaneamente e o herói prontificou-se a libertar a princesa, matando o monstro em troca de sua mão.

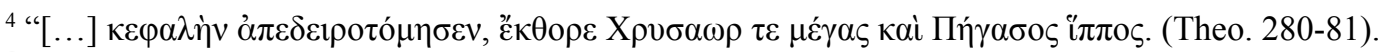

${ }^{5}$ Os gregos utilizavam o termo "etíope" para designar os africanos que fossem dotados de uma coloração de pele mais escura que a dos egípcios. Segundo o dicionário Lidell-Scott-Jones (LSJ), o termo significa "face-queimada", isto é, "etíopes, negros". Por sua vez, o dicionário Middle-Scott (MS) traz as acepções de "propriamente face-queimada, isto e, um etíope, africano - em sentido homérico" e ainda "etíope, enquanto adjetivo herodotiano", enquanto o dicionário Slater avoca o sentido de "etíope" como substantivo masculino plural. Disponível em:

http://www.perseus.tufts.edu/hopper/morph?1=ai\%29qio\%3Des\&la=greek\#Perseus:text:1999.04.0057:ent ry=*ai (recuperado em 12 de maio de 2018).

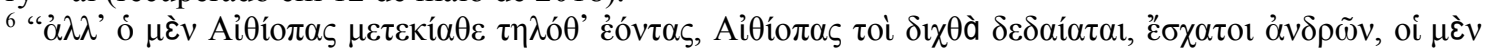

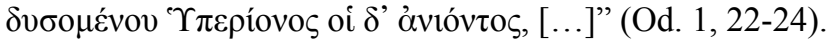

${ }^{7} \mathrm{Na}$ Andrômeda euripidiana, Perseu teria chegado à praia onde Andrômeda estava exposta, voando; na Andrômeda sofocliana, a leitura dos fragmentos remanescentes, indica duas possibilidades: que o herói tivesse atingindo o local, a pé ou voando.
} 
Para os historiadores, as tragédias produzidas no contexto dos festivais dramáticos da Atenas Clássica constituem uma inestimável documentação histórica, a despeito das complexidades que envolvem as interpretações desses textos. É necessário jamais esquecer que se tratam de produções poéticas centradas em eventos mitológicos compostas mediante a ambição do autor em vencer a competição e que, para tanto, deveriam agradar um restrito grupo de juízes e, da mesma forma, emocionar um amplo e diversificado público. Não obstante, as tragédias tenham sido escritas e representadas por homens; objetivando contemplar uma grande audiência masculina, nos chama atenção que dentre as obras remanescentes de Ésquilo, Sófocles e Eurípides, houvessem tantas protagonistas femininas advindas das narrativas míticas, enfrentando e refletindo acerca de questões referentes as atenienses do século $\mathrm{V}$ a.C.

Naturalmente, significativos contrastes separavam as heroínas trágicas, conforme aponta Deborah Lyons "as mulheres famosas (chamadas 'esposas e filhas dos melhores homens') que Odisseu encontrou em sua descida ao submundo na Odisseia" e "algumas das mais poderosas figuras femininas do mito que, de fato, compartilham muitas características comumente atribuídas aos heróis masculinos" (Lyons, 1996, p.10), de suas congêneres da Atenas Clássica. De fato, as heroínas achavam-se no centro da ação, enquanto as atenienses - mesmo que inseridas no sistema social encontravam-se marginalizadas de suas instituições centrais. As mulheres da ficção exteriorizavam com veemência sentimentos e opiniões que as suas contrapartes humanas eram incentivadas a reprimir. Por certo, em que medida as inquietações das heroínas trágicas corresponderiam à condição das atenienses da polis clássica?

Buscamos conferir visibilidade aos papéis atribuídos e desempenhados pelas mulheres atenienses e meroítas do século V a.C. Com esse intuito, privilegiamos o uso dos textos trágicos e das pinturas em vasos cerâmicos, enquanto suporte documental. Conferir evidência às mulheres no mundo antigo implica em apresentar alternativas aos papéis femininos normalmente apresentados pela historiografia tradicional, de modo a "romper com os modelos homogeneizantes de mulher, por exemplo, a mulher grega que é considerada pelo campo historiográfico como uma eterna menor devido sua dependência à figura masculina" (Candido, 2012, p. 9).

O encontro de Perseu e Andrômeda despertou o interesse de Eurípides, que compôs a tragédia Andrômeda, provavelmente encenada pela primeira vez no ano de 412 a.C. - integrando uma trilogia com Helena e Ifigênia em Tauris. Por sua vez, a data 
da primeira performance da peça homônima escrita por Sófocles não chegou até nós. De acordo com E. Petersen (1903, p.99), “o romântico conto da bela princesa Andrômeda, e como Perseu a libertou do dragão foi abordado por dois dos maiores trágicos, Sófocles e Eurípides". A temática do herói que resgata a donzela em perigo vincula-se diretamente a temática do sacrifício humano, e geralmente é associado ao bem comum, sendo recorrente em numerosos textos trágicos. Conforme aponta Wilson Ribeiro (2009, p.261), "no contexto dos usos e costumes que beneficiam a comunidade, em detrimento do bem e dos interesses particulares de cada um, deve ser inserida a mítica prática do sacrifício humano, tema de diversas tragédias".

Devido ao alcance social obtido pelas encenações teatrais não era incomum que os ceramistas registrassem nos vasos composições figurativas que remetessem aos textos trágicos e cômicos. Através dos vasos cerâmicos podemos resgatar aspectos cênicos como vestimentas, máscaras, disposição do coro e, em alguns, constam os nomes de atores ou personagens. A expressiva quantidade de cerâmicas ornamentadas com cenas teatrais, atesta a relevância social do teatro para os atenienses e o profundo impacto individual exercido pelas peças, posto que "o público adquiria esses vasos para recordar o que já conhecia; os artistas os pintavam para as pessoas que já haviam visto as obras e que identificavam as cenas e sentimentos que elas haviam gerado" (Dukelsky \& Martino, 2002, p.6).

Nossa pesquisa favorece as tragédias de Andrômeda de Eurípides e Sófocles enquanto documentação textual. Por sua vez, utilizamos o instrumental metodológico da Análise do Conteúdo, como proposta por Maria Regina Candido, visto que nos possibilita sistematizar conceitos que, preliminarmente, se apresentam de maneira velada no discurso poético. Segundo a autora "documentos de sociedades antigas, fora do tempo e do espaço, fragmentos de textos, palavras, gestos, artefatos e imagens deixam de ser objetos de uma determinada época para se transformarem em suporte de informação de conhecimento que nos permite elaborar um texto analítico e crítico" (Candido et al. In Beltrão et al., 2011, p. 13).

Para a análise das imagens utilizaremos a metodologia da semiótica que possibilita examinar documentos como artefatos, imagens, palavras e gestos, de modo a decifrar os códigos dos signos, significações e demais dados, posto que "imagem é de fato uma linguagem, uma linguagem específica e heterogênea; que, nessa qualidade, 
Mare Nostrum, ano 2020, v. 11, n. 1 .

distingue-se do mundo real e que, por meio de signos particulares, propõe uma representação escolhida e necessariamente orientada" (Joly, 2007, p.48).

A utilização do repertório iconográfico oriundo da cerâmica como instrumento de análise aos estudos acerca do papel feminino na sociedade grega figura entre as vantagens da aproximação disciplinar entre História e Arqueologia. Como nossa pesquisa se dedica à investigação da proximidade entre a realeza grega e cuxita, privilegiaremos a Arqueologia de Gênero, “essa inovadora prática arqueológica pretende encontrar as funções de mulheres e homens, assim como seus espaços, em nosso passado, através do estudo da cultura material do ser humano" (Marti, 2000, p. 142).

Estabelecido nosso instrumental teórico e metodológico, nosso texto discorrerá acerca dos múltiplos intercâmbios realizados entre Europa e África através do Mar Mediterrâneo, e de aspectos gerais da realeza grega e cuxita, destacando os papéis atribuídos às mulheres da realeza.

\section{Considerações sobre a África Mediterrânica}

Se, atualmente, percebemos a estrutura física do Mar Mediterrâneo enquanto fracionada - tanto do ponto de vista topográfico quanto ambiental -, para os povos da Antiguidade que o singraram, suas águas foram desde suas origens consideradas como uma totalidade. Enquanto um mar intercontinental, o Mediterrâneo se constitui em um corpo de água com 2,5 milhões de quilômetros quadrados de extensão, situado entre o sul da Europa, o norte da África e a região sudoeste da Ásia. Em direção ao leste se avizinhava com Oceano Atlântico através do Estreito de Gibraltar. Em termos estruturais, o Mediterrâneo estava dividido em bacia oriental e ocidental, separadas pela península Itálica e Sicília. Entretanto, devemos destacar que não se tratam de espaços semelhantes, mas, antes, distintos, visto que as bacias situadas ao longo do norte da África e região do Levante próximas a regiões costeiras recuadas ofereciam abrigos seguros às embarcações. Encerrado entre continentes, as águas do Mediterrâneo foram influenciadas por montanhas, vulcões, planaltos, planícies e florestas, localizadas ao seu redor. Todavia, as forças climáticas da Europa não o afetavam tanto quanto o Saara, o maior deserto da Terra, que praticamente domina a região norte da África. 
Diante da convergência entre mar e deserto, a região norte do continente africano desenvolveu uma geografia e clima peculiares, de sorte que passou a ser denominada de África Mediterrânea (Broodbank, 2014; Braudel, 2002; Mabogunje, 2010; Porteres \& Barrau, 2010). Durante a Antiguidade, compreendia a Mauritânia, Tripolitania, Cirenaica e o delta do Nilo. Por efeito dos influxos do Mediterrâneo e do Saara, apresentando um arranjo de clima quente e seco, bem como um panorama caracterizado por montanhas, ilhas planaltos, zonas úmidas e desérticas, o solo árido se apresentava propício ao cultivo do trigo, cevada, leguminosas, oliveiras e alfarrobeiras.

Reconhecendo a existência de itinerários marítimos que favoreciam as trocas entre o Mediterrâneo e suas áreas adjacentes, destacamos o protagonismo do Rio Nilo - que garantia o acesso pelo mar ao interior da África. Assim, “o vale do Nilo tornou-se a rota privilegiada entre o norte e o sul do continente, e foi através desse vale que se realizaram os vários tipos de intercâmbio entre a África negra e o Mediterrâneo" (Mokhtar \& Vercoutter In Mokhtar, 2010, p. xxxvi). Braudel igualmente menciona a relevância da região que se estendia de Bahr el-Ghazal até alcançar o Mediterrâneo ao norte, onde o Nilo "esvazia suas águas frescas e lamacentas longe no mar" (Braudel, 2002, p. 36).

Os contatos entre as sociedades mediterrâneas e africanas por meio das rotas marítimas para além da troca de bens econômicos, promoveu o escoamento de informações que, por sua vez, contribuiu para difundir padrões culturais, especialmente em relação à filosofia e à religião. Consideramos relevante destacar a proposta de Irad Malkin em A Small Greek world: Networks in the Ancient Mediterranean (2011), que nos permite compreender a origem e desenvolvimento de redes de comunicação na Antiguidade, "vínculos, planejados e aleatórios, rapidamente reduziram a distância entre os nós da rede, transformando o vasto Mediterrâneo e o Mar Negro em um 'mundo pequeno', um termo que define a teoria atual das redes" (Malkin, 2011, p.5). Os padrões duradouros de relações entre atores sociais, ou seja, indivíduos, formam estruturas. E dentro desse ambiente de estruturas, através dos caminhos criados pelos grupos, informações e ideias, recursos e serviços podem ser transmitidos. Nesse sentido, Candido (2017, p. 238) propôs, à guisa de tradução, a nomenclatura de Teoria da Conectividade Social, destacando os processos de colonização grega no mar Egeu, Mediterrâneo e Negro. 
O trânsito marítimo através do Mediterrâneo viabilizou os contatos e trocas entre Europa e África, Grécia e Cuxe, de modo que podemos constatar que as remotas relações entre esses povos, conectados pelo Mediterrâneo, estenderam-se ao longo dos séculos seguintes. Apesar da distinção estabelecida pelos gregos em relação aos demais povos - os barbarikós (oi $\beta \alpha \rho \beta \alpha \rho \iota \kappa^{8} \varsigma^{8}$ ) -, os primeiros mantiveram sua predisposição em admirar aspectos da vida dos não-gregos, tanto aqueles que consideravam avançados, como os egípcios e persas, quanto povos percebidos como primitivos, a dizer, os citas. Como veremos a seguir, mediante o testemunho dos textos trágicos e dos registros da arte cerâmica, as relações travadas entre Grécia e Cuxe foram duradouras e pautadas pela admiração e cordialidade.

\section{Aspectos da realeza cuxita: a XXV dinastia}

O Reino de Cuxe encontrava-se localizado na Núbia, território esse que durante séculos viabilizou o contato entre a região central da África e o mundo mediterrâneo, oferecendo acesso por meio das quatro direções cardinais e figurando como uma "verdadeira encruzilhada de caminhos africanos, um ponto de encontro das civilizações do leste e do oeste, do norte e do sul da África, sem esquecer as do Oriente Próximo, da Ásia distante e da Europa mediterrânica" (Adam \& Vercoutter In Mokhtar, 2010, p. 215).

As origens de Cuxe relacionam-se diretamente a vínculos entre os povos núbios e egípcios, que desde o III milênio a.C., por serem geograficamente próximos, produziram culturas materiais expressivamente semelhantes. Subsequentemente, enquanto os núbios viveram sob o seminomadismo, observando algumas práticas agrícolas e optando pelo pastoreio, os egípcios desenvolveram um sistema administrativo centralizado e adotaram a plantação irrestrita, sem que essas diferenças comprometessem sua interação "à existência de laços estreitos entre o alto e o baixo vale do Nilo. Sua origem cultural comum, que não deve ser negligenciada, favoreceu os intercâmbios" (Adam \& Vercoutter In Mokhtar, 2010, p. 222).

\footnotetext{
8 Conforme o Dicionário de Grego-Português (v. 1, p. 163), "bárbaro; não grego; estrangeiro; comportar-se como um bárbaro".
} 
Tratando-se do Egito, durante a vigência da III até a VI dinastias; os monarcas preocuparam-se efetivamente em consolidar políticas de anexação territorial, objetivando granjear recursos materiais da região ocupada por populações núbias. Entretanto, em 2200 a.C., podemos distinguir a hesitação do propósito expansionista egípcio e a chegada do Grupo C no corredor Núbio. Nagm-El-Din Sherif pondera acerca das diversas hipóteses para as origens da cultura do Grupo C salientando que, apesar de seu contato com o Egito, se desenvolveu culturalmente à margem de sua influência. Afirma o autor: "a despeito do crescente contato com o Egito, a cultura do Grupo C continuou a desenvolver-se de maneira independente, sem adotar nem a tecnologia, nem a escrita, nem as crenças religiosas egípcias" (Sherif In Mokhatar, 2010, p. 245). Possivelmente em razão da momentânea ausência egípcia, por volta dos anos de $2.200 \mathrm{a}$ 1.580 a.C., o Grupo C se instalou em definitivo na Baixa Núbia - área entre a Segunda Catarata, Assua e Batn-el-Haggar. Conquistando prosperidade econômica e desenvolvimento cultural, mesmo diante da influência egípcia, consolidou-se como o reino autônomo de Cuxe.

Não obstante, os faraós da XII dinastia comprometeram-se com a retomada das políticas de anexação territorial e a decorrente fixação de novas fronteiras, voltando sua atenção para a zona da Segunda Catarata e suas adjacências meridionais. Esse movimento sinalizaria alguma preocupação dos monarcas egípcios com a garantia de segurança para seu território contra uma eventual ameaça militar por parte dos cuxitas? Ao longo dos séculos subsequentes, os faraós adotaram políticas que oscilaram ora em impor a influência egípcia de forma contundente sobre Cuxe, ora em afastar-se para resolver as contendas internas e externas do Egito. Entretanto, entre 1550 e 1295 a.C., os cuxitas voltam ao subjugo da XVIII dinastia, passando a render tributos, travar relações comerciais e, gradualmente, aderir aos costumes egípcios. Mesmo as convulsões religiosas verificadas durante a dinastia seguinte, não comprometeram o equilíbrio do reino cuxita, que permaneceu sob a administração de vice-governadores advindos da realeza egípcia.

Contudo, durante o Terceiro Período Intermediário (1070-710 a.C.), no qual reinava a XX dinastia, podemos observar o retorno das antigas disputas pelo trono do Egito travadas entre a realeza da situação, potências estrangeiras e novos grupos sociais. Silva se refere a uma rebelião ocorrida durante o governo de Ramsés XI: “o vice-rei de Cuxe, Peneasi, a reprime, em nome do rei. Em nome deste, restaura a ordem no Alto 
Egito e passa a governá-lo". Porém, a conduta irascível do governante gerou descontentamento na população, e "as forças que lhe eram hostis arregimentam-se em torno de Herior, que se tornara sumo sacerdote de Âmon, em Tebas, e de Esmendes, que talvez dele fosse filho" (SILVA, 2006 p.120-21). Após a morte de Ramsés XI, os opositores tebanos de Peneasi fundaram sua própria dinastia - a XXI - inaugurando um período de instabilidade política que se estendeu até a XXV dinastia, também denominada etíope.

Composta pelos herdeiros da realeza autóctone os reis da XXV dinastia governaram o Egito e Cuxe da capital Napata em meados do século VIII a.C. Essa era uma cidade localizada próxima da Quarta Catarata e da montanha Jebel Barcal, e acomodava o Templo de Âmon, “o que permite avaliar a importância de Napata como sede da realeza e centro religioso durante o período mais antigo da história de Kush" (Hakem, Hrbek \& Vercoutter In Mokhtar, 2010, p. 318).

Em verdade, a presença egípcia em Napata entraria em declínio somente a partir da XX dinastia sem comprometer, contudo, o prestígio religioso que a cidade alcançara em virtude do templo de Âmon. Segundo Dunham, “o controle político, sem dúvida, fora relaxado durante as XX e XXI dinastias, no final da XXII, Cuxe se tornou, na verdade, se não nominalmente, independente" (Dunham, 1946, p.384). Essa situação possibilitou que Napata gradualmente se consolidasse como sede de uma nova força política com amplo respaldo religioso, dada a influência exercida pelos sacerdotes do templo de Âmon, cujas articulações foram decisivas para a consolidação da XXV dinastia.

Livres da presença egípcia, a classe sacerdotal passou a exercer as funções administrativas e políticas de Napata. Cientes da necessidade de poderio militar os sacerdotes buscaram os nobres locais e legitimaram sua autoridade, viabilizando que essa nova linhagem autóctone governasse Napata. Conforme apontam A. M. Ali Hakem, I. Hrbek e J. Vercoutter "vários outros traços - o sistema de eleição, o papel das rainhas-mães, os costumes funerários e outras indicações - sugerem claramente a existência de uma cultura e de uma origem indígenas, livres de influências externa" (Hakem, Hrbek \& Vercoutter In Mokthar, 2010, p. 297-98).

Não obstante as dificuldades em determinar os primeiros reis da dinastia, as escavações realizadas por G. A. von Reisner no século XX, na necrópole de El Kurru, 
revelaram cinco gerações de reis napatanos, bem como a identidade daquele ao qual se atribuiu a fundação da XXV dinastia: Kashta, que teria governado Napata em meados do século VIII a.C. O rei conquistou Tebas e ainda teria obrigado a suma sacerdotisa de Âmon a adotar sua filha, Amenirdis, e, assim, assegurou a sucessão das princesas cuxitas nesse prestigioso cargo.

Ao analisarmos o processo sucessório da XXV dinastia, nos chama atenção uma singular característica a respeito dos expedientes da sucessão régia. Um primeiro olhar prenuncia que o estatuto de faraó era transmitido entre irmãos. Assim, "o poder passava, após a morte do rei, para seu segundo irmão, e depois, para cada um dos irmãos sobreviventes. Findos estes, ia recair no filho mais velho do que primeiro fora rei, retomando-se depois a linha de irmão para irmão" (Silva, 2006, p.130). Todavia, se na XXV dinastia a sucessão era estabelecida pelo parentesco masculino porque o príncipe Taharqa, para justificar sua reivindicação ao trono, enfatizou que sua mãe, a rainha Abale, era uma das irmãs de Alara, um dos reis que o antecedera?

Reconhecendo as distinções dispensadas às mulheres da realeza do período napatano - mães, esposas, irmãs e filhas -, podemos inferir que o sistema sucessório cuxita se orientava pela descendência matrilinear. Ao longo governo da XXV dinastia, que unificou o Egito e Cuxe, outros príncipes com aspirações ao trono distinguiram sua linhagem feminina e contaram com a participação de suas mães em suas cerimônias de coroação. Consoante defendem Hakem, Hrbek e Vercoutter, o faraó “Anlamani (- 623 a -593) [sic] descreve em termos semelhantes os episódios das festas de coroação em Gemáton (onde foi descoberta a estela) e acrescenta ter trazido sua mãe para assistir às cerimônias, como fizera Taharqa antes dele" e da mesma forma, "para justificar suas pretensões ao trono, Aspelta invoca não só a vontade do deus Âmon-Rá como também a sua própria origem (afirmando, assim, o direito hereditário de sucessão através da linhagem feminina) (Hakem, Hrbek \& Vercoutter, In Mokthar, 2010, p. 299-300).

Além do relevante papel desempenhado pela rainha nos processos sucessórios e de legitimação do pretendente ao trono, as princesas da XXV dinastia desempenhavam a função de sacerdotisas de Âmon, "o grande deus da dinastia, adorado em quatro santuários principais - Napata, Torá (provavelmente Sanam), Kawa e Pnubs (Tabo, na ilha de Argo). Para o serviço de cada um desses santuários eram consagradas princesas, como musicistas de Âmon” (Leclant In Mokthar, 2010, p. 277). 
É imprescindível mencionar que, tratando-se de sociedades antigas, encontramos numerosos elementos em narrativas míticas que podem ser cotejados segundo seu valor histórico, uma vez que “mito está - ou esteve muito recentemente - 'sendo vivido', no sentido de fornecer modelos para o comportamento humano e, por esse mesmo fato, atribuir sentido e valor à vida" (Eliade, 1963, p. 2). Dessa forma, como uma princesa cuxita da cidade de Méroe, Andrômeda teria desempenhado a função de sacerdotisa de Âmon - condição essa que se soma à carga religiosa de seu sacrifício. Como referido na Andrômeda, de Sófocles, "ela foi designada vítima sacrificial pela polis, pois há um costume entre esses Bárbaros de a Cronos sacrificar um ser humano, desde os tempos antigos" (Ribeiro, 2009, p. 264). Da mesma forma, Andrômeda, de Eurípides, contém alusões ao sacrifício da princesa como imposição divina: “ó infeliz, frágil é a sorte que o deus te deu, mas elevadas são tuas palavras"10 (Crepaldi, 2016, p. 365).

A exposição de Andrômeda ao monstro marinho foi amplamente representada na cerâmica ática, como podemos observar na cratera com volutas ${ }^{11}$ de figuras vermelhas com adição de cores, de 425 a 400 a.C.; na cratera cálice ${ }^{12}$ de figuras vermelhas, atribuída ao Pintor Cleofón por Beazley, datada de 475 a 425 a.C.; e na cratera cálice ${ }^{13}$ de figuras vermelhas em fundo branco, atribuída ao Pintor Fiale por Beazley, de 475-425 a.C.

De modo a realizar uma leitura que nos permita identificar aspectos relacionados com as práticas sacerdotais das rainhas a partir das cenas representadas na cerâmica ática, mencionamos a análise imagética e os usos de determinados vasos, proposta por Candido. A autora resgata a atuação das sacerdotisas nos ritos atenienses das Anthestérias, destacando o registro presente na cerâmica, "o vaso stammos de figuras vermelhas datado de 420 a.C. nos apresenta a imagem de madeira do deus Dionisos, ornamentado com flores, rodeado de mulheres que tanto podem ser as

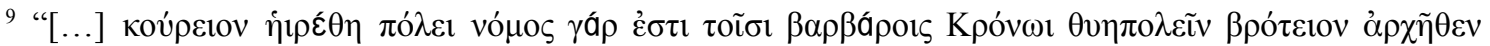

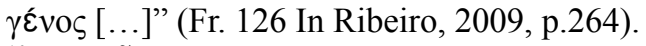

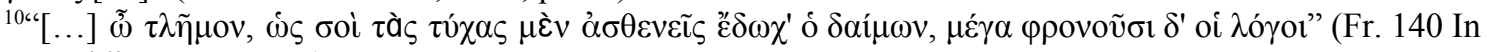
Crepaldi, 2016, p. 365)

11 Atualmente integra a coleção do Museu Paul Getty (Malibu, Estados Unidos). Disponível em: http://www.beazley.ox.ac.uk/record/0B8638F0-600D-40C1-8172-6129BF9070AF (recuperado em 12 de maio de 2018).

${ }^{12}$ Atualmente integra a coleção do Museu Antigo e Coleção Ludwing (Basileia, Alemanha). Disponível em: http://www.beazley.ox.ac.uk/record/C078B8DE-F3A2-43B4-82D8-2707AF0980C5 (recuperado em 12 de maio de 2018) .

13 Atualmente integra a coleção Museu Arqueológico Regional (Agrigento, Itália). Disponível em: https://izi.travel/it/0320-il-museo-archeologico-regionale-pietro-griffo-di-agrigento/it\#57d0-perseo-e-la-li berazione-di-andromeda/it (recuperado em 12 de maio de 2018).
} 
menades[sic]/bacantes assim como as gerairai", o que a leva a "supor que a ação nos aponta para o rito de preparação da mistura do vinho com água a ser distribuído aos convivas do banquete" (Candido, 2011, p.4). Entendemos que o mesmo processo poder ser realizado de maneira a conferir visibilidade ao papel social desempenhado pelas mulheres da realeza cuxita enquanto sacerdotisas de Âmon.

Preliminarmente, nas três cenas representadas nos vasos nos chama atenção o fato de Andrômeda achar-se ricamente vestida, como convém a uma princesa e sacerdotisa. Por certo, o séquito feminino da realeza cuxita trajaria vestimentas que, aos olhos dos gregos, pareceriam bárbaras. Como descreveu Lohwasser, "possivelmente as mulheres cuxitas amarravam um rabo de animal, como um amuleto que garantia a fertilidade, junto ao joelho ou à panturrilha, e que pendia abaixo do vestido" (Lohwasser, 2001, p. 63).

A seguir, destacamos a presença de Cefeu na imagem da cratera com volutas e na cratera cálice, atribuída a Cleofón. Sua vinda ao local do sacrifício da filha, para além do amor paternal, sinaliza-nos o estatuto do sacerdócio de Andrômeda, tendo em vista a prática comum dos reis cuxitas em ofertarem suas filhas para servirem no templo de Âmon. Segundo a tradição cuxita, o rei Kashta teria forçado a Shepenoupet, suma sacerdotisa de Âmon em Tebas, a adotar sua filha Amenirdis e, a partir de então todas as princesas cuxitas passaram a ocupar o cargo, “com privilégios quase reais, as Amenirdis e as Shepenoupets constituíram uma espécie de dinastia paralela, com sucessão de tia para sobrinha" (Leclant In Mokthar, 2010, p. 277).

As mulheres da realeza cuxita - mães, irmãs, primas, sobrinhas - ocupavam relevantes papéis no séquito dos reis da XXV dinastia. Enquanto a mãe alicerçava a conexão do rei com os antepassados, intercedia junto a Âmon e, sem sua presença, não ocorreria a coroação. Por sua vez, a filha, sacerdotisa do deus, assistia-o nas cerimônias. A irmã provia-lhe herdeiros e, a esposa atuava como o componente feminino que complementava o poder régio. Por certo, segundo afirmou Lohwasser, "sem o aspecto feminino, o governo não funcionaria” (Lohwasser, 2001, p. 74). 


\section{Aspectos da realeza grega: os reis homéricos}

Após o colapso das estruturas palacianas da sociedade micênica ocorrido no século XII a.C., os testemunhos arqueológicos apontam para uma escassez material manifesta na decadência e posterior abandono de importantes assentamentos do período. Ademais, segundo Snodgrass, "quando somamos a isso a queda drástica na quantidade, como sugere a redução de mais de três quartos da população, então é certamente inconcebível que a prosperidade se mantivesse constante" (Snodgrass, 1971, p. 357).

Nesse sentido, destacamos a relevância dos épicos, Ilíada e Odisseia, atribuídos ao aedo Homero que podem viabilizar aos historiadores, significativas informações acerca dos nos finais desse período subsequente ao declínio do mundo micênico, tradicionalmente denominado de "Idade das Trevas".

Atualmente, entre grande parte dos especialistas da temática predomina a tendência em situar a consolidação dos poemas homéricos - tal como a contemporaneidade os conhece - no século VIII a.C. Tal data marca o fim de um recorte cronológico da história da Grécia que teve seu “início no século XI, quando o mundo grego havia se estabelecido em sua 'Idade das Trevas', um período de declínio e recuperação lenta, que durou até o século VIII” (Pomeroy, 2004, p. 36).

Admitindo que os fatos relatados por Homero como a guerra de Troia e o regresso dos heróis sobreviventes tenham ocorrido nos anos finais do século XII a.C., fica evidente que nem mesmo um exímio poeta como Homero poderia recriar de forma autenticamente histórica uma sociedade tão afastada de sua própria temporalidade, cuja preponderância e referências encontram-se presentes na Ilíada e Odisseia. Isso posto, destacamos a obra "O mundo de Homero" (2002), de Pierre Vidal-Naquet, na qual o historiador propõe a existência de um "mundo homérico" percebido enquanto uma síntese poética entre um passado micênico idealizado e uma realidade histórica consolidada.

À vista disso, devemos salientar que, embora Homero não tenha cantado sobre as façanhas de Perseu, o herói insere-se no passado micênico que o aedo procurou imortalizar, posto que, filho da princesa de Argos, ele integrava a linhagem real de Argos como descendente de Io. Após desposar Andrômeda, Perseu retornou em sua companhia para a ilha de Séfiro, onde reencontrou-se com Dânae e, juntos, dirigiram-se 
para Argos, pois Perseu desejava encontrar-se com Acrísio. Acidentalmente o herói causou a morte do idoso rei e, por isso, rejeitou o trono. Posteriormente, fez arranjos para governar Tirinto, onde estabeleceu sua própria linhagem real.

Assim sendo, nos chama atenção o protagonismo que Homero conferiu aos membros da nobreza, narrando as atividades de seu cotidiano, como os trabalhos domésticos diários, o lazer em família, as disputas esportivas, as reuniões políticas, o fausto de suas moradas e as práticas de comensalidades. Tais descrições levaram Richard Janko a concluir que a iniciativa para registrar os poemas homéricos teria partido de um próspero mecenas. Segundo o autor, "na Jônia do século VIII, o número de pergaminhos necessários para uma tarefa similar representaria uma grande despesa. Isso nos limita a cortes de ricos príncipes e nobres", de maneira que, "apenas uma motivação cultural ou ideológica poderia impulsionar o desejo de registrar esses épicos" (Janko, 1998, p. 12).

Nos poemas, a realidade feminina foi retratada de forma paralela à masculina por meio das exigências sociais que estabeleciam as esferas e papéis das mulheres e homens. Às primeiras, cabiam as tarefas de manutenção do lar e da família enquanto os segundos, se ocupavam da guerra e do discurso. Nesse sentindo, o emprego do conceito de gênero viabiliza nossa compreensão das funções sociais exercidas por mulheres e homens revelando sua complementariedade, visto que, "sublinha também o aspecto relacional entre as mulheres e os homens, ou seja, que nenhuma compreensão de qualquer um dos dois pode existir através de um estudo que os considere totalmente em separado" (Soihet In Cardoso \& Vainfas, 2012, p. 404).

No que diz respeito às mulheres da realeza homérica - tais como filhas e esposas de heróis -, se esperava que no exercício das funções de esposas, administrassem os trabalhos domésticos do lar e gerassem filhos legítimos ao marido. O casamento figurava como uma oportunidade para que as famílias adquirissem bens materiais e fundamentassem alianças militares. Para Finley, "entre outras coisas, ele servia para estabelecer novos ramos de parentesco; ele instituía assim essa rede de obrigações mútuas que se entrecruzavam através do mundo grego" (Finley, 1982, p. 148).

Com efeito, na Grécia homérica o casamento estabelecia vínculos entre famílias poderosas e, tratando-se da união entre moradores de localidades distintas, a escolha da residência do novo casal era determinada em meio a uma complexa síntese entre 
Mare Nostrum, ano 2020, v. 11, n. 1 .

tradição e condições econômicas, políticas e militares que visavam o benefício das famílias envolvidas. Nesse sentindo, segundo Pomeroy, podemos verificar a existência de dois tipos de arranjos matrimoniais: "no modelo patrilocal, o pretendente trazia a noiva para sua própria casa, e esta era usada como uma primeira pedra na nova aliança entre as casas de seu marido e de seu pai"; e em contrapartida, "no modelo matrilocal muitas vezes era um cavaleiro viajante que se casava com uma princesa e se estabelecia nos domínios de sua esposa; portanto, a sucessão ao trono nesse caso era matrilinear" (Pomeroy, 1999, p. 34).

O sistema matrilinear achava-se relacionado a comunidades que praticavam o sedentarismo e a agricultura, nas quais a mulher desempenhava papéis produtivos preponderantes, visto que as técnicas de cultivo e estocagem dos alimentos se achavam sobre seu apanágio. Seu trabalho junto à gleba assegurava a obtenção dos provimentos necessários à alimentação diária, de forma que a mulher personificava "o valor máximo da vida e da produção agrícola: a estabilidade. Suas atividades no cultivo garantiam o sustento da coletividade, enquanto os homens desempenhavam funções arriscadas, incertas ou até economicamente prejudiciais à comunidade, como a caça e a pesca" (Larkin, 2008, p.75).

Diante da relevância social da atividade econômica exercida pelas mulheres, os critérios para determinar a filiação se constituíam em um desdobramento dessa relação entre homens e mulheres, ou seja, eram estipulados em benefício do cônjuge que permanecia junto a sua linhagem. Portanto, em comunidades sedentárias imperava o sistema matrilinear, posto que os homens figuravam como elemento estrangeiro da relação. Como afirmou Diop, "no sedentarismo, a filiação será matrilinear uma vez que é o homem que é estrangeiro e que sua mulher pode, a qualquer altura, repudiar este caso não cumpra suas funções conjugais" (Diop, 2014, p.33).

Segundo Heródoto, os pelasgos encontravam-se entre os primeiros habitantes da Grécia, que adeptos do sedentarismo e da agricultura, articulavam uma forma antiga da língua grega, da qual sobreviveram poucos elementos linguísticos em certos topônimos. Considerando a origem dos gregos, pela perspectiva da narrativa mítica, Finkelberg menciona que "a genealogia grega padrão é aberta com o stemma de Deucalião, que inclui Heleno e seus descendentes" para finalmente "terminar com stemmas menores, como o dos descendentes de Pelasgos" (Finkelberg, 2005, p.33). O domínio pelasgo foi abalado pela chegada de uma transumância estrangeira que alcançou a Grécia, por volta 
do terceiro milênio a.C., chegando através da região dos Bálcãs, mas cujo epicentro original é de difícil localização. Dada a proporção de sua zona de influência territorial, eram chamados de indo-europeus ou arianos, tendo em comum, o uso da mesma língua, conforme analisa Gladstone de Melo, "convencionou-se chamar indo-europeias, indo-germânicas ou áricas, as línguas que constituem transformações históricas de um idioma extinto, falado com unidade há cerca de cinco mil anos por um povo que hoje denominamos árias" (Melo,1975, p.87).

Desse modo, podemos supor que a síntese que deu origem ao povo grego se verificou mediante a união matrimonial das mulheres da realeza nativa com príncipes estrangeiros, tal como nos relatam diversas narrativas mitológicas, conforme aponta Finkelberg, "Belerofonte foi da Grécia para Lícia, onde se casou com a filha do rei e se tornou rei. Pélops migrou na direção oposta e tornou-se rei de Elis exatamente da mesma maneira" (Finkelberg, 2005, p.66).

Poderia argumentar-se que em situações de ausência de herdeiros masculinos; seria imposto aos reis legarem o trono ao marido de suas filhas. Entretanto, no caso da sucessão real espartana, o rei Tindaro possuía dois filhos, Castor e Pólux, que se envolveram ativamente na escolha do legatário paterno, o qual seria o futuro marido de sua irmã, Helena. Assim, a princesa desposa o estrangeiro Menelau que, dessa forma, adquire a condição de rei espartano.

Na Ilíada é relatado que Helena deixou Esparta e o leito de seu esposo para seguir em direção a Troia, chegando a contrair segundas núpcias com troiano Páris-Alexandre. Por esse motivo, os gregos declararam guerra contra a cidade de Príamo e reivindicaram a devolução imediata da rainha espartana e seus tesouros. Conforme afirmou Pomeroy, "Menelau era rei em virtude de sua situação de marido de Helena, poderia perder seu trono se a perdesse. Por isso, recusou aceitar aquela troca de maridos e determinou-se a recuperá-la, como requisito essencial para sua pretensão ao trono de Esparta” (Pomeroy, 1999, p. 36). Com efeito, após a queda de Troia, todas as mulheres da realeza troiana, sofreram um destino atroz nas mãos dos reis e guerreiros gregos. Sacrificadas, violentadas ou reduzidas à escravidão, foram despojadas de seus antigos estatutos. Menelau, todavia, não infligiu qualquer dano a Helena e, antes, conduziu-a para Esparta onde ambos restituíram a convivência matrimonial, conforme narrado na Odisseia. 
Nesse mesmo poema, podemos identificar outro exemplo do sistema matrilinear de sucessão ao trono, manifesto na questão das segundas núpcias de Penélope. Considerada viúva, seu novo marido governaria Ítaca. Os ouvintes da Odisseia não ignoravam que Laertes reinara sob Ítaca, sendo sucedido por Odisseu. Entretanto, poucas evidências indicavam que Telêmaco poderia assumir o trono de Ítaca e, ao que tudo indicava, o próximo rei da ilha seria um dos nobres locais que então cortejava Penélope. Nos cantos iniciais da Odisseia, o aedo relata como as investidas românticas dos jovens, gradualmente, converteram-se em vilanias após serem alertados sobre o ardil da rainha, que postergou sua escolha durante quatro anos sob a justificativa da confecção de um sudário para seu sogro Laerte. Lê-se na Odisseia: “de dia, tramava a enorme urdidura, e à noite desenredava-a com tochas postadas ao lado" ${ }^{14}$, (Od., 2,103-4). Dessa forma, os pretendentes passaram a frequentar diariamente o palácio de Odisseu, consumindo seus víveres e desfrutando dos favores sexuais das servas.

Os ceramistas áticos registraram o papel das rainhas no sistema matrilinear de sucessão ao trono - ao que destacamos as cenas nas quais são perseguidas ou assediadas. São exemplos a cratera $\operatorname{sino}^{15}$ ática de figuras vermelhas, de $c a$. 440-430 a.C., que traz Menelau atrás de Helena, e o escifo ${ }^{16}$ beócio de figuras negras do século $\mathrm{V}$ a.C., que retrata Penélope sentada próxima ao tear - instrumento tradicionalmente associado à rainha - e rodeada por alguns pretendentes.

$\mathrm{Na}$ cratera sino, podemos distinguir a figura de Helena, ornada com coroa, que corre em direção ao altar fugindo da perseguição de Menelau. Esse, por sua vez, larga a espada em um gesto de não violência - atitude que nos leva a inferir que o guerreiro pretendia recuperar a esposa, sem feri-la. No escifo, estamos inclinados a acreditar que os ceramistas optaram por registrar o episódio em que Penélope foi surpreendida pelos pretendentes enquanto desfazia o sudário de Laertes à noite, conforme observa-se na passagem da Odisseia: "por meio de servas, cadelas insolentes, eles me pegaram, e com palavras me repreenderam. E assim completei a mortalha a contragosto, obrigada.

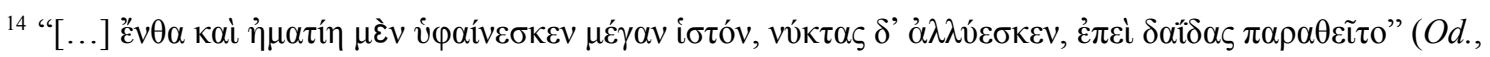
$2,103-104)$

15 Atualmente integra a coleção do Toledo Museum of Art (Toledo, Espanha). Disponível em: http://www.perseus.tufts.edu/hopper/artifact?name=Toledo\%201967.154\&object=Vase (recuperado em 12 de maio de 2018).

${ }^{16}$ Atualmente integra a coleção do Fogg Art Museum, Museum of Fine Arts, (Boston, Estados Unidos) Disponível em: https://www.harvardartmuseums.org/collections/object/291687?position=05/ (recuperado em 12 de maio de 2018).
} 
Agora não consigo mais escapar das bodas nem outro plano mais intento"17 (Od. 19. 154-58).

Ao discorrermos acerca do sistema matrilinear de sucessão ao trono, é imprescindível mencionar que essa primazia das rainhas na escolha do rei achava-se respaldada em seu papel enquanto sacerdotisas da deusa-mãe autóctone, cujo culto relacionava-se às práticas agrícolas e obtenção de fertilidade. Por essa razão, elas tornavam-se transmissoras do poder régio, “ou seja, onde quer que o reinado pelo casamento fosse praticado como um padrão regular de sucessão, em vez de uma linhagem de reis, teríamos uma linhagem de rainhas que iria de mãe para filha" (Finkelberger, 2005, p. 68).

A mesma relevância do papel desempenhado pelas rainhas sacerdotisas aparece na obra hesiódica. No Hino a Hécate, o poeta assinala como essa deusa recebeu distinções de Zeus, o que leva-nos a supor que Hécate integrava uma linhagem da realeza palaciana, uma vez que "a narrativa mítica de Hesíodo traz a prerrogativa de mulheres-sacerdotisas que tinham como responsabilidade a realização de rituais para trazer a riqueza para o palácio, a fertilidade a criação e prosperidade aos negócios" (Candido, 2016).

De fato, os poemas homéricos não oferecem relatos diretos de que Helena ou Penélope atuassem como sacerdotisas, não obstante, o aedo mencione como as rainhas desempenhavam atividades claramente relacionadas ao sagrado: Helena possuía conhecimentos sobre drogas terapêuticas (Od., 4, 219-32) e interpretava prodígios (Od., 15, 171-76); e, por sua vez, Penélope sonhava com presságios (Od. 4,795-837; 19, 535-50), realizava os ritos domésticos (Od., 17, 57-60), chegando a atribuir a inspiração para o ardil do sudário de Laertes à influência divina $(O d ., 19,138)$.

Por certo, estamos diante de um sistema de sucessão ao trono orientado por critérios matrilineares no qual a mulher - a princesa, que eventualmente tornar-se-ia rainha -, dispondo de incumbências religiosas, conferia a soberania ao seu consorte. Por seu turno, "a rainha - e o poeta não hesita em empregar esse termo - dispõe de uma parte do poder que diferencia o rei dos demais nobres, e pode, portanto, transmiti-lo. Esse poder, como já foi mencionado, é de natureza religiosa” (Mossé, 1990, p.27).

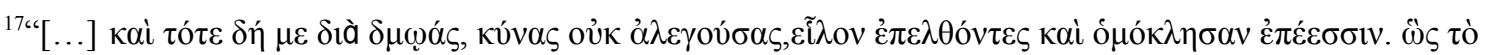

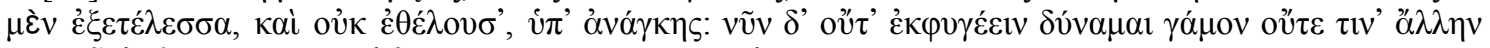

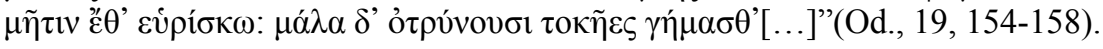




\section{Considerações finais}

Nossa breve exposição distinguiu o mito de Perseu e Andrômeda como pressuposto para uma análise histórica acerca da conectividade, mediada pelo mar Mediterrâneo verificada entre Grécia e Cuxe desde o século VIII a.C. Tal conectividade foi registrada tanto pela narrativa mitológica como também foi retomada pelos trágicos e ceramistas áticos da Atenas Clássica. Para tanto, escrutinamos as práticas matrimoniais - entendidas enquanto instrumento formador de alianças -, buscando evidenciar as peculiaridades dessa prática nas realezas grega e cuxita. Como suporte documental, utilizamos as versões de Eurípides e Sófocles de Andrômeda e os vasos que representavam o encontro entre o herói grego e a princesa cuxita. De modo a analisar o papel feminino durante a Antiguidade, favorecemos o uso dos conceitos de Gênero e de Arqueologia de Gênero, além de utilizarmos a Análise do Conteúdo e a Semiótica enquanto instrumental metodológico para compreendermos as minúcias textuais e imagéticas presentes em nossa documentação.

Inicialmente, discorremos acerca do papel fundamental desempenhado pelo mar Mediterrâneo na promoção de diversas formas de trocas ocorridas entre a Europa e África e, nessa perspectiva, evidenciamos a existência da noção de um mundo mediterrânico, cuja geografia singular favoreceu o desenvolvimento de uma multifacetada rede de comunicações estabelecida ao longo da Antiguidade - tal como apregoa Malkin quando aventa a Teoria da Rede Social.

A seguir, empreendemos uma investigação acerca de Cuxe, cujo enfoque foi o surgimento e o fim da cidade de Napata - primeira capital e centro religioso - e seu estreito vínculo com a dinastia XXV, posteriormente denominada de "dinastia etíope". A dinâmica sucessória dessa linhagem era estabelecida segundo os princípios da matrilinearidade, de maneira que as mulheres da realeza participavam amplamente da vida pública de Cuxe: a mãe do rei desempenhava papel fundamental na cerimônia de entronamento do novo rei; a esposa partilhava do poder de governar e a filha do rei, atuava como sacerdotisa no templo de Âmon. Por essa altura, foi possível identificarmos pontos de contato entre a narrativa mítica de Andrômeda e os aspectos históricos das mulheres da dinastia XXV. Apesar das condições fragmentadas dos textos trágicos de Eurípides e Sófocles, foi possível constatar que os poetas aludiram 
prerrogativas notórias do mito que, em alguma medida, foram representados pelos ceramistas nos vasos.

Em relação à Grécia homérica, percebemos que também vigorava o sistema sucessório matrilinear mediante o casamento de um príncipe estrangeiro com uma princesa nativa: a herdeira da rainha, que atuava como sacerdotisa da deusa-mãe divindade feminina autóctone associada ao sucesso das práticas agrárias. Tanto na Andrômeda euripidiana quanto na sofocliana, vislumbramos o tema do herói forasteiro que se une à donzela local.

Diante do exposto, percebemos que a narrativa mítica oferta testemunhos acerca da proximidade cordial entre as realezas grega e etíope. Em Homero, encontramos as primeiras alusões aos etíopes, e no mito de Perseu e Andrômeda retomado pelos trágicos e ceramistas áticos da Atenas Clássica evidencia-se a maneira pela qual a polis se utilizava desse passado heroico para refletir acerca de suas questões sociais mais preeminentes.

Recebido em 15.12.2020, aprovado em 13.04.2020. 
Mare Nostrum, ano 2020, v. 11, n. 1 .

\section{REFERÊNCIAS BibLIOGRÁficas}

Fontes:

Hesiod. Theogony. (1914). (Hugh G. Evelyn-White, trad.). Cambridge, MA.,Harvard University Press; London, William Heinemann Ltd.

Hesíodo. (2003). Teogonia: a origem dos deuses. (Alves Torrano, José Antônio, trad.). (5 ed.). São Paulo: Iluminuras.

Homer. The Odyssey. (1919). (Murray, A.T., trad.) Cambridge, MA., Harvard University Press; London, William Heinemann, Ltd.

Homer. (1920). Homeri Opera in five volumes. Oxford, Oxford University Press.

Homero. (2003). Ilíada de Homero. (de Campos, Haroldo, trad.). (Volume I e II). São Paulo: Arx, Homero. (2014). Odisseia. (Werner, Christian, trad.). (1 ed). São Paulo: Cosac Naify.

Eurípides. (2016) Andrômeda. (Lacerda Crepaldi, Clara, trad.). In: Estudos Linguísticos e Literários, $\mathrm{n}^{\circ}$ 55, Núm. Especial, Salvador.

Sófocles. (2009). Andrômeda. (Alves Ribeiro, Wilson, trad.). In: Classica (Brasil), 22.2, 261-269, 2009.

Estudos:

Adam, S. \& Vercoutter, J. (2010). A importância da Núbia: um elo entre a África central e o Mediterrâneo. In: Mokthar, G (ed.). História geral da África, II: África antiga. (pp.235-273) UNESCO.

Beltrão, C.R. et al.(2011). A Busca do Antigo. Trarepa, Nau.

Candido, M. R. et al. (2011). Novas perspectivas sobre a aplicação metodológica em História Antiga. In: Rosa, C. B. da et al. (Coord.). A Busca do Antigo. Trarepa, Nau. 
Marina Outeiro. "O amor que temos é terrível".

Candido, M. R. (2012). Mulheres na Antiguidade: Novas Perspectivas e Abordagens. UERJ/NEA; Grafica e Editora-DG.

Candido, M. R. et al. (2016). Os espaços sagrados da deusa Hécate Ctonia na Atenas Clássica. Palestra. I Colóquio Internacional de Estudos Greco-Latinos - Espaços do sagrado na Cidade Antiga. Espírito Santo.

Diop, C.A. (2014). A unidade cultural da África Negra: Esferas do patriarcado e do matriarcado na Antiguidade Clássica. Edições Mulemba da Faculdade de Ciências Sociais da Universidade Agostinho Neto.

Dukelsky, C. \& Martino, A.M (2002). Imágenes em la pintura de vasos griegos. In: Revista do Museu de Arqueologia e Etnologia, (12), 71-79.

Eliade, M. (1963). Myth and Reality. Harper \& Row, Publishers.

Finkelberg, M. (2005). Greeks and Pre-Greeks: Aegean Prehistory and Greek Heroic Tradition. Cambridge University Press.

Finley, M. I. (1982). O mundo de Ulisses. Presença.

Ginzburg, C. (2007). Mitos, emblemas, sinais: morfologia e história. (2. Ed). Companhia das Letras.

Hakem, A.M.; Hrbek, I.; Vercoutter, J. (2010). A civilização de Napata e Méroe. In: Mokthar, G (ed.). História geral da África, II: África antiga (pp. 297-332). UNESCO.

Hitchner, R. B. (2009). The Mediterranean and the History of Antiquity. In Erskine, A. A Companion to the Ancient World (pp. 429-435). Blackwell Publishers Ltda.

Hugot, H.J. (2010). Pré-História do Saara. In: Ki-Zerbo, J. História geral da África, I: Metodologia e pré-história da África (pp. 657-684). UNESCO.

Janko, R. (1998). The Homeric Poems as Oral Dictated Texts. The Classical Quarterly, 48 (1), pp. 1-13.

Joly, M. (2007). Introdução à Análise da Imagem. Lisboa: Edições 70. 
Mare Nostrum, ano 2020, v. 11, n. 1 .

Ki-zerbo, J. (2010). História geral da África, I: Metodologia e pré-história da África, Brasília: UNESCO.

Larkin, E.N. (2008). (org.). A matriz africana do mundo. São Paulo: Selo Negro.

Leclant. J. (2010). O Império de Kush: Napata e Méroe. In: MOKTHAR, Gamal. História geral da África, II: África antiga. Brasília: UNESCO.

Lohwasser, A. (2001). Queenship in Kush: Status, Role and Ideology of Royal Women. Journal of the American Research Center in Egypt, (38), 61-76.

Lyons, D. (1996). Gender and Immortality: Heroines in Ancient Greek Myth and Cult. Princeton University Press.

Malhadas, D. \& Dezotti, M. C. C. \& Neves, M. H. M. (2006-2010). Dicionário Grego-Português (DGP). Ateliê Editorial.

Malkin, I. (2011). A Small Greek World: Networks in the Ancient Mediterranean. Oxford University Press.

Martí, R. F. (2003). La Arqueologia Del Gênero: espacio de mujeres, mujeres con espacio. Espagrafic.

Melo, G. C. (1975). Iniciação à filologia e à lingüística portuguêsa. Acadêmica.

Mokthar, G. (2010). História geral da África, II: África antiga. UNESCO.

Mossé, C. (1990). La mujer en la Grecia clásica. Editorial Nerea.

Petersen, E. Andromeda. (1904). The Journal of Hellenic Studies, (24), 99-112.

Pomeroy, S. B. et al. (2004). A brief history of Ancient Greece: politics, society, and culture. Oxford University Press.

Pomeroy, S. B. (1999). Diosas, rameras, esposas y esclavas: mujeres en la Antigüedad Clásica. Ediciones Akal.

Scott, Joan Wallach. (1995). Gênero: uma categoria útil de análise histórica. Educação \& Realidade. 20 (2), 71-99. 
Marina Outeiro. "O amor que temos é terrivel".

Sheriff, A. M. H. (2010). A costa da África oriental e seu papel no comércio marítimo. In: Mokhtar, G. (ed.) História geral da África, II: África antiga. (pp. 607-626) UNESCO.

Silva, A. C. (2006). A enxada e a lança: A África antes dos portugueses. Nova Fronteira.

Snowden, F. M. (1970). Blacks in Antiquity: Ethiopians in the Greco-Roman Experience. Harvard University Press.

Soihet, R. (1997). História das Mulheres, In: Cardoso, C.F.; Vaifas, R. Domínios da História: ensaios de teoria e metodologia (pp. 399 - 429) Campus.

Vainfas, R., (1997). História das Mentalidades e História Cultural, In: Cardoso, C.F.; Vaifas, R. Domínios da História: ensaios de teoria e metodologia (pp. 189-241). Campus. 
Mare Nostrum, ano 2020, v. 11, n. 1 .

\section{"The Love We Have Is Terrible": The Contacts Between The Greek And Kushite Royalty Manifested In The Union Of Perseus And}

\section{Andromeda}

Marina Pereira Outeiro

Abstract

We discuss the contacts established between Greek and Kushite royalties from the myth of Perseus and Andromeda - retaken by Euripides and Sophocles in Classical Athens in their versions of Andromeda, and by ceramists who represented the encounter between the Greek hero and the Kushite princess. We privilege the theoretical contributions from Gender Studies and Gender Archeology to analyze the roles attributed to women in both societies. For the examination of the evidence, textual and imagery, we favor the use of Semiotics and Content Analysis.

KEYWORDS

Greece; Kush; Andromeda; Perseus. 